\title{
TUNNEL CHANNEL PROJECT VERSUS 3rd BRIDGE PROJECT OVER THE BOSPHORUS STRAT*
}

\author{
Orhan ŞENER ${ }^{* *}$
}

\begin{abstract}
This project deals with the problems of landroad dominated transportation system in Istanbul, and compares the social costs and benefits of Channel Tunnel (tube) and 3rd Bridge Projets respectively. Although, cost-benefit analysis of both projects proves that, the Channel Tunnel Project is indispensible with regard to principles of public economy. But, this project has been postponed, since big business successfully exerted heavy influence over the politicians in favour of 3rd Bridge Project over the Bosphoros.

The Channel Tunnel Project not only generates positive external economies in the forms of decreasing death toll and pollutions, saving the foresty areas; and reducing the petroleum consumption etc, but it also helps to connect the high speed train projects of EC countries to East Asia. For this reason, this project should be considered as an international public goods benefiting many countries and calls for contribution of nations be financed collectively. On the other hand, extension of Tunnel Project through high speed trains to Antalya, Urfa via Ankara and Trabzon will also contribute to the establishment of infrastructure of Turkish economy by encouraging tourism and industry.
\end{abstract}

* This paper has been submitted to the International Conference of Public Finance held in Kyoto, 25-28 August 1997, Japan

** Professor, Faculty of Economics and Administrative Sciences, and EC Institute, Marmara University [institute1@superonline.com]. 


\section{Introduction}

Turkey has a railway network which is about 6 times shorter than the EC average, calling for landroad dominated transportation system, both in national and local levels. Overallocation of sources to private sector caused many type of socioeconomic problems, such as: high death toll in traffic accidents, overconsumption of imported oil in land transportation; air, water and noise pollution; increase in the cost of goods and services, decreasing productivity in the economy etc. In addition to these problems city transportation in Istanbul causes considerable time loss and congestion. In order to solve these problems, three different rail based project have been prepared so far. The one is a metro project and the others are a suburban train and a Channel Tunnel Project under the Strait of Bosphorus. Among these projects only the metro project is being realized. As to Channel Tunnel Project concerned, two projects was prepared but ceased up to now. However, the third project is being prepared by a consortium of American, German and Turkish construction firms. On the other hand a 3rd Bridge Project is being dissussed and a Japanese firm proposed to built a bridge which can be used both rail and land transportation. It seems to me none of these alternative projects is likely to be chosen due to financial, administrative and political reasons. This is why, I wanted to do a descriptive study on cost-benefit analysis of Channel Tunnel versus 3rd Bridge Project over the Bosphorus.

My paper includes the following topics: after giving a brief information about the structure of Turkish transportation system a cost benefit analysis of 3rd Bridge Project and Channel Tunnel Project will be developed. In order to compare the respective costs and benefits of these alternative projects, indirect tangible costs of 3rd Bridge Project are classified first.

Since pressure groups play very important role in the selection process of the project, some cases have been noted in order to show how they efect the politicians. In the last section of the paper, a theoretical evaluation of the cost benefit analysis will be made with respect to developing countries.

\section{a) The Structure of Turkish Transportation System}

As it is shown in tables below, Turkish transporation system is overwhelmingly land oriented. The first table comprises the shares of the different transportation modes in passenger carriage. Whereas, the second one shows the freight carriage by the various modes of transportation, in terms of realization percentages in the years of 1989 and 1994 , and the estimated values for the year of 2000 by the State Planning Organisation. ${ }^{1}$ 


\section{Table 1: Percentage distribution of Passenger Carriage}

\begin{tabular}{lrrr} 
& $\underline{1989}$ & $\underline{\mathbf{1 9 9 4}}$ & $\underline{\mathbf{2 0 0 0}}$ \\
Highways & 95.2 & 95.4 & 95.5 \\
Railways & 3.5 & 2.9 & 2.4 \\
Seaways & 0.1 & 0.02 & 0.03 \\
Airways & 1.3 & 1.7 & 2.03 \\
\hline
\end{tabular}

The table shows that the share of the public transportation is less than $5 \%$ which can't be compared to western countries. As to freight carriage is concerned, the share of public transportation is also not important as shown below.

\begin{tabular}{|lrcr|}
\hline \multicolumn{4}{c|}{ Table 2: Percentage distribution of Freight Carriage } \\
& $\underline{1989}$ & $\underline{1994}$ & $\underline{\mathbf{2 0 0 0}}$ \\
Highways & 71.09 & 87.95 & 82.48 \\
Railways & 8.2 & 8.19 & 10.2 \\
Seaways & 8.77 & 0.60 & 0.81 \\
Airways & 1.12 & 0.2 & 0.27 \\
Pipelines & 15.83 & 8.32 & 13.45 \\
\hline
\end{tabular}

Both systems at national and regional levels, based heavily on private and land transportation modes, generates considerable externalities. These negative externalities generally take the forms of;

- High death toll,

- Overconsumption of imported oil,

- Heavy dependence on car producing countries,

- Adverse effect on foreign trade balance,

- Public bads; such as air, water and environmental pollutions 
- Increase in cost of producing goods an services in general,

- Thus, inflationary process can't be taken under the control,

- Decrease in the mobility of people due to higher transportation expenses,

- And many tangible and intanglibe social costs that will be explained specifically in the following cost benefit analysis of 3rd Bridge Project versus Channel Tunnel Project.

Among these negative externalities the high level of death toll is being considered to be the most important issue in Turkey. Although every type of administrative measures have been taken so far, but the number of the people killed and injured in the traffic accidents is increasing. Some blame for the easily obtainable drivers licenses as the result of deregulation and others charge the administration not to take preventive measures to cope with traffic accidents. But it seems to me the most important reason is closely related to the private transporation dominated structure of the economy as shown by the table 1 and 2 above.

\section{b) Modes of Transportation in the City of Istanbul}

More or less the same transportation structure exists in the city of Istanbul, as in the case of national level. Accordingly, about $90 \%$ of the passengers is carried by the private modes of road transportation, whereas $5 \%$ by the rail and the rest of $5 \%$ is by the sea transportation means. On the other hand, about 7.5 million people out of more than 10 million of total population of the city is commuted through different modes of transportation as shown in below table ${ }^{2}$

Table 3: The shares of modes of transportation in Istanbul

Mode of Transportation

Buses (municipality and private)

Minibuses (all private)

Private cars

Service buses (mostly private)

Rail

Sea lines

Taxi and dolmus (shared taxi)
Its share (\%)

25

23

18

15

7

8

6 
Thus, approximately, $65 \%$ of the passengers are carried by the private modes of transportation, owned by 33.000 business firms. About $35 \%$ of the passengers take more than one transportation means. More than 800.000 people cross the Bosphorus Strait through the existing 2 bridges and by boats.

As a matter of fact that, I found a strong relationship between the decreasing death toll and the public transportation dominace. As the rail transportation becomes important in a country, the number of killed people in the traffic accidents decreases rapidly. Accordingly, even though the number of the motor vehicles is much more greater in developed countries compared that of in Turkey, but the death toll per vehicle is less in former countries owing to improved rail transportation. ${ }^{3}$ For this reason, the death toll shows a decreasing tendency in developed countries, while it increases in Turkey, (See Graph 1).

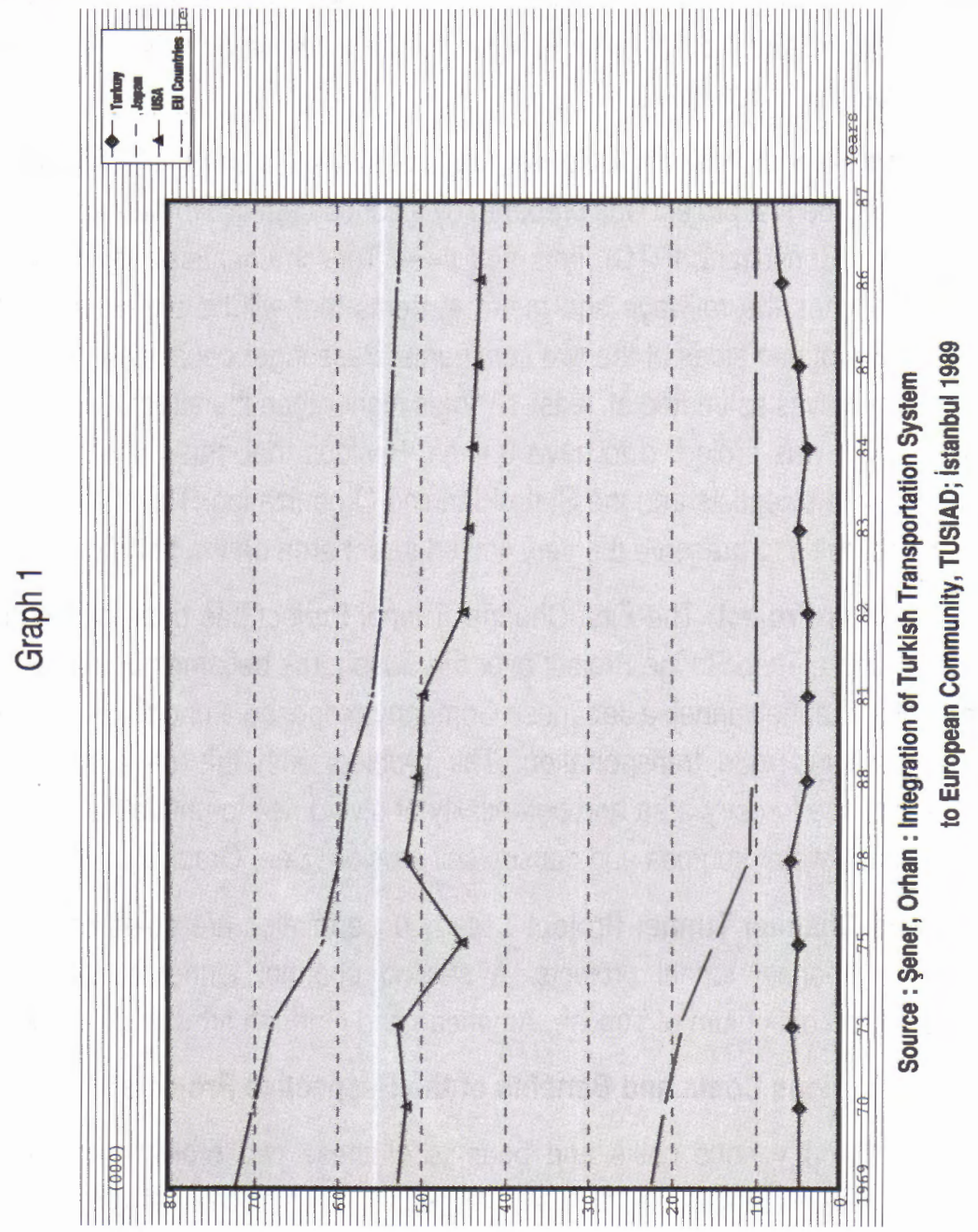




\section{c) Cost/Benefit Analysis of Channel Tunnel and Third Bridge Projects}

Many projects have been prepared to integrate the metro, intercity and international railways, through a channel tunnel under the Bosphorus so far. But none of these has been put into effect yet, due to heavy pressures of the interest groups exerted on the governments and lack of political support.

A French company first proposed a project of tube passage to Ottoman Sultan connecting Asian and European sides in 1860's. During those years Paris and London metros was about to start. But, Ottoman Sultan rejected the project of tunnel passage and only a short metro was constructed, instead. It is the shortest metro in the world, having no station between the entrance and exit points. Although the trip lasts only 1,5 minutes, but it helps to solve the transportation problem between two heavily populated trade areas.

Channel Tunnel Project: As far as a channel tunnel under the Bosphorus Strait is concerned, the first project was prepared by a concortium of two American (Istanbul Rail / Tunnel Consultant, IRTC) firms and three Turkish counterparts in 1985. This project integrates the railways and metro systems that will be undertaken, in both Asian and European sides of the two continents. Passenger capacity of the Channel Tunnel Project was estimated at least 10 times higher than the alternative 3rd Bridge Project, which was projected to have 6 lines. Besides that, this project was highly admired by the scientists and the State Planning Organization. The Channel Tunnel Project also helps to preserve the very limited forest area on the north of the city.

3rd Bridge Project: The First Channel Tunnel Project has been ceased by the politicians and a Third Bridge Project over the Bosphorus became popular in 1990's. Instead of a channel tunnel, a Japanese Company proposed a bridge project suitable for both rail and road transportation. The problem with this project is that, it's closeness to the forestry area and potentiality of giving rise to unhealthy settlements which pollutes water sources and causes soil erosion (See, Graph 2).

Second Channel Tunnel Project : Many uncertainties are going on about the bridge and channel tunnel projects. A second channel tunnel project is being prepared by a concortium of Turkish, American and German firms for the time being.

\section{d) The Various Costs and Benefits of the Respective Projects}

In identifying various costs and benefits of these two projects, the following categories may be distinguished. Firstly, respective costs and benefits of these two 


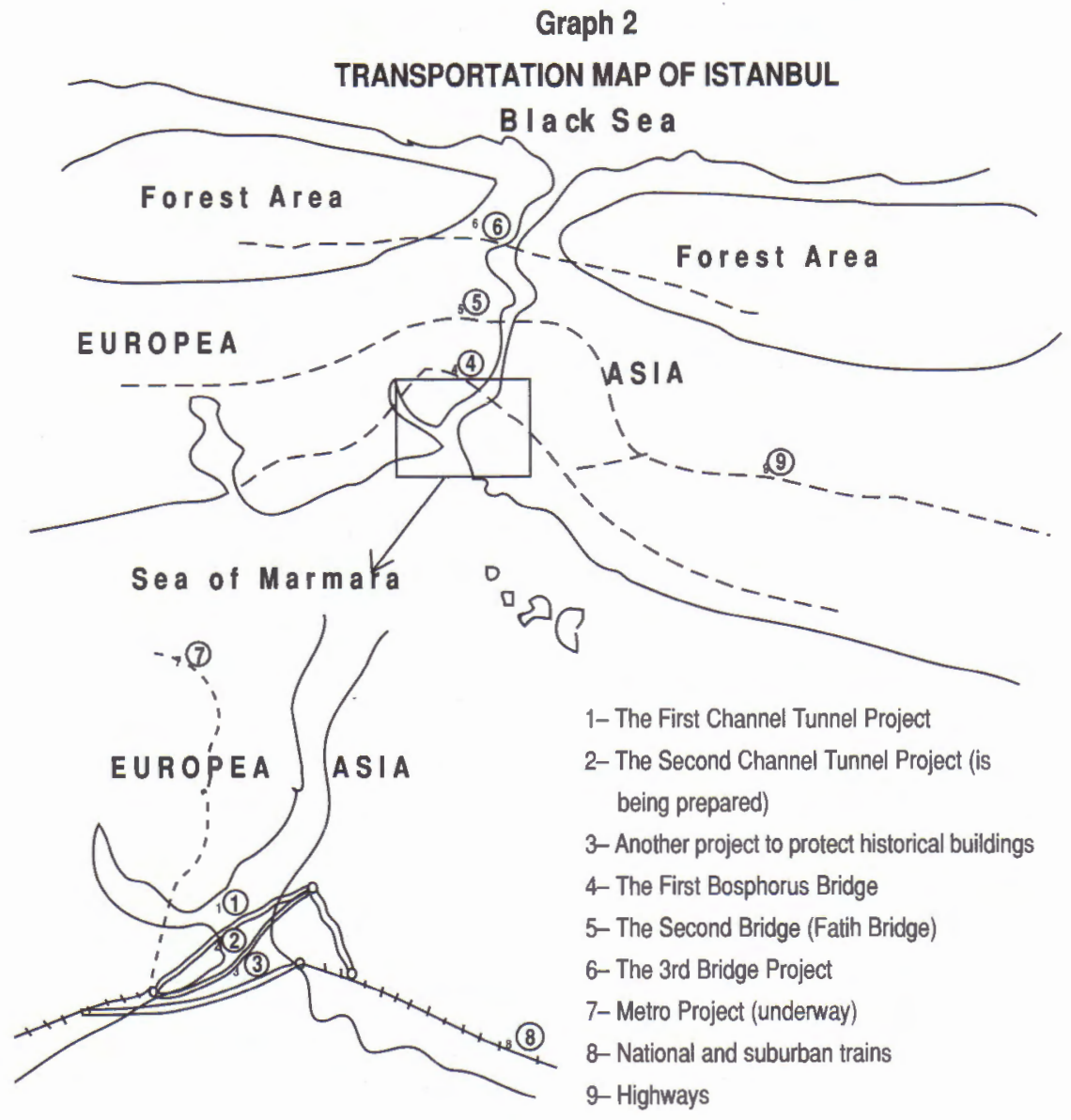

projects may be real or pecuniary (in monetary terms). Secondly, real (or social) costs and benefits may be in the form of direct or indirect; tangible or intangible as Musgrave classified. ${ }^{4}$

The real (or social) benefits are the benefits derived by the society, reflecting an addition to the real cost of resource withdrawals from other uses. For this reason, an important decrease in the number of the people killed in the roads, would be a good example of the real benefit of the Channel Tunnel Project. On the other hand, increase in the number of the people in the traffic accidents includes the real (or social) cost of the 3rd Bridge Project. 
Real (social) costs and benefits of the public projects may be direct (primary) and indirect (secondary). While the direct costs and benefits are closely related to objectives of the main projects. For this reasons, direct costs and benefits accrue to those people who are related to the project. Thus the direct cost becomes external or private costs and the direct benefits are received as private or internal benefits of the people who are involved in the projects. The direct (internal) benefits of the Channel Tunnel Project is reduced travelling expenses. While the indirect (external) benefit of the same project is decreasing level of inflation and improvement in unfair income distribution in Turkey.

The direct cost of 3rd Bridge Project is likely to have increased foreign payments deficit, as the result of excess consumption of imported oil. This will in turn wil result in an indirect (external) cost which will decrease the welfare of society, due to prevailing devaluation.

Pecuniary benefits and costs of the public projects result in changes in the relative prices rather than welfare increases to the society. For this reason, gains and losses accrue to some individuals, balanced against others who loss and gain as the result of projects. Examples of the pecuniary cost of 3rd Bridge Project would be in the form of bribes and commissions taken by the politicians and bureaucrats. On the other hand, pecuniary benefits of the same project would be appreciation of the lands nearby the bridges and high increase of the income of real estate speculators and owners of the lands. But, these pecuniary changes don't reflect net gains to society, because they are matched by offsetting losses of the low income groups who have to pay higher rents

The marketable costs and benefits are tangible, whereas the nonmarketable ones are referred as intangible. Thus, beautification of the area nearby the 3rd Bridge is an intangible benefit in nature.

On the other hand, distortions of the value judgements of the citizens as the result of bridge project, in the form of mafia type of economic activities should be considered as the intangible cost of it. Examples of intangibles also includes a corrupted society with the mayors, politicans and officials as bribe takers.

For this reason, after giving some brief information about the relative costs and benefits of public work, l'll try to identify the possible merits and demerits of both projects. In doing so, some important features of respective costs and benefits will be identified as follows. 


\section{a) Indirect Tangible Costs of The 3rd Bridge Project}

In the following explanation of the cost-benefit analysis of the Channel Tunnel versus 3rd Bridge Project, a descriptive statement of the respective costs and benefits is preferred since, the cost benefit analysis of different public projects are not employed in Turkey. For this reason, important elements of social costs and benefits of this two projects are classified as I consider, as shown below.

1. Increasing Deficit in Foreign Trade Balance: More than the $1 / 4$ of the imported oil is consumed in road transportation in Turkey. 3rd Bridge Project is likely to increase the foreign trade deficit accordingly, because it encourages motor vehicle based transportation.

2. Dependence on Car Producing Countries: Due to having conspicuous consumption type of demand motivation, many people prefer foreign cars to homemade ones. It is estimated that, the share of the foreign cars in total motor vehicles exceeds the $34 \%$. For this reason, importation of cars will also increase the demand for spare parts calling for foreign trade deficit. ${ }^{5}$

3. High Level of Confiscation Indemnity: 3rd Bridge Project involves in construction of many new roads, passages and highways in the metropolitan area. This will result in payment of higher confiscation indemnities to the homeowners and nationalization outlays to landowners.

4. Housing Problems: Confiscation of many houses causes the increase in the number of the homeless families. Thus, demand for the new houses increases rapidly, This will in turn increases the value of the speculated lands, as a result of 3 rd Bridge Project.

5. Low Quality Housing: 3rd Bridge Project calls for construction many roads encouraging new settlement projects where the squatter houses are predominate. In Turkish these low quality houses are called "gecekondu", which means that a house built without acquiring the land rights. They are generally built at night (or gecekondu) not to take the attention of the authorities. Even though, the authorities are aware of the fact.

6. Socio-Economic Problems Increase: Settlement around the roads from the bridges, attracts the homeless people. Thus, the overpopulated squatter areas become the shelter for the potential criminals. 
7. Soil Erosion: New roads leading to the very limited forest area on the north, result in loss of many trees. In fact, these areas are preferred by the wealthy people to built villas. Thus, exploitation of forests causes soil erosion problem.

8. Water Pollution: As a by-product of Bridge Project, new roads are built approaching to the areas where the water sources are reserved. In recent years, water reserve areas and the lakes were heavily polluted by the squatters and the villas.

9. Noise Pollutions: Due to unhealthy urbanization, traffic is not distributed among the streets appropriately. For this reason, motor vehicle traffic in main streets causes heavy noise problem as in the case of industrial countries.

10. Air Pollution: Researches done by the municipality and a team from the Technical University of Istanbul, reveals that more than $50 \%$ of the air pollution is motor vehicles related. Thus, substitution of natural gas for coal in heating is not likely to solve the problem. Because, natural gas is not widely used and it's price is increasing rapidly.

11. Increase In The City Population: Since the authorities and the political parties are very tolerant to the squatter (gecekondu) type of settlement, population of Istanbul has risen rapidly. During the election peridos, penalties with regard to illegal settlements are generally pardoned. This encourages new settlements.

12. Migration is Encouraged: Squatter type of settlement policy attracts many people from the other cities and villages, who are seeking for new employment opportunities. As a matter of fact that, many people migrate to Istanbul hoping to benefit from the rent that the bridge projects generated. Because, they make a lot of money after getting the legal status of their illegally obtained squatter land.

13. Bribery and Corruption: Although their de facto status is not recognized by the authorities, the squatter housing is maintained in exchange for different type of corruption. Corruptions may take the form of giving bribe to the civil servants or supporting a political party in general elections or a mayor in local election.

14. Costly Public Services: As the squatter type of settlement becomes dominant in the suburban area, the cost of public utilities such as gas, electricity, water and transportation increases. Because, it becomes very costly to provide public utilities due to lacking of infrastructure in rular areas. 
On the other hand, illegal use of electricity by the owners of the squatters is not charged on the basis of user charge pricing formula. Besides that, families with many children enjoy lower prices for use of water, in order to encourage population increase in the city of Istanbul. This idea is openly supported by the Mayor of the metropolitan city of Istanbul

15. Congestion Problem: Since roads in the metropolitan area is not wide enough to accommodate increasing number of vehicles, serious congestion problems occurs. Bridge projects have contributed a lot to the congestion of traffic.

b) The Indirect Benefits of the Channel Tunnel Project

The above staded indirect tangible costs of he 3rd Bridge Project will completely be eliminated, provided that Channel Tunnel project is realized. The following examples include different type of indirect tangible benefits of the Channel Tunnel Project. Classification of various benefits also shows the fact that, how the indirect tangible costs of the 3rd Bridge Project is repealed and reversed through Channel Tunnel Project.

1. Improvement in Foreign Trade Balance, will likely occur since electricity will be substituted for imported oil consumption. This will also relieve the high inflation rate which became a structural problem.

2. Decreased dependence on foreign car producing countries, as a result of improved public transportation system. Because, many people will likely to use public transportation and this will result in decrease in the demand for foreign cars and spare parts.

3. Public savings from the confiscation indemnities will be increased, since 3rd Bridge Project is withdrawn. On the other hand, metro projects don't involve in confiscation problems.

4. Opportunity cost of confiscated houses and lands is reduced, because Channel Tunnel Project doesn't result in decrease in the number of the homes and shops.

5. Since roads leading to forest area will not be opened under Tunnel Project, water resources and reserves are protected at no extra cost.

6. Same reasoning applies to preservation of forest area. In addition to protection of forest from speculators, Tunnel Project also helps to protect and maintain the wildlife. 
7. Rail related projects are not likely to generate speculation on land and housing. Thus the sources of the corruption and unfair income distribution can be easily eliminated through Channel Tunnel Project.

8. Squatter (or gecekondu) type of settlement is not encouraged by metro project, for this reason the cost of constructing houses is not likely to increase. Because, speculation on land will not be possible under Channel Tunnel Project.

9. Over population problem of Istanbul will be easily taken under the control. Since, speculative motives wil disappear under metro project. For this reason Channel Tunnel is not likely to attract many people to Istanbul

10. Cost of public utilities will not rise as in the case of 3rd Bridge project. Because, migration movements from less developed areas to Istanbul is not encouraged under Channel Tunnel project.

11. Since slums and squatter type of settlement are discouraged, socio economic condition will be improved.

12. Congestion in the city traffic will be reduced to some greater degree, resulting in less air pollution.

13. Rapid transportation through metro will help to reduce average commuting time from 4 hours to 1 hour.

14. Channel Tunnel project will also help to protect the environment and is likely to take under the control of air, water and noise pollution.

15. Since many car owner will prefer to take metro trains, number of the cars parked on the streets will be decreased. This will enable the people to walk on the streets comfortably.

\section{c) Indirect Intangible Cost of 3rd Bridge Project}

3rd Bridge Project not only generates external diseconomies as stated above, but it is also likely to result in many type of psychological disorders, distress, trouble, worny, depression and boredom as classified below.

1. Noise pollution generated by the motor vehicles make the people get nervous and causes insomnia.

2. Especially, working people get very tense due to congestion related lateness to the job. 
3. Transferring at least three modes of transportation on going to office is very boring and time consuming. Same applies returning from the office to home.

4. Alternative cost of time lost in commuting is too high. It is estimated that, the average commuting time is about 4 hours in Istanbul, while it is less than I hour in western metropolitans. As a matter of fact that many people have no time to enjoy themselves.

5. Coming late to home due to heavy traffic creates family problems. Kids may not see their parents till the weekends.

6. Uncomfortable travelling experience on account of very crowded buses and minibuses.

7. Polluted air is breathed, because of crowded land transportation means.

8. One has to listen to the music played by the driver, even though it is not appreciated.

9. Insecurity felt by the padestrians while walking in the pavements, because sideways are already occupied by the private cars.

10. Tensions caused by the fear of being late to the job.

11. Resettlement problems and inconvenience as the result of being homelessness due to bridge project.

12. Bribes given to land mafias and authorities which is incompatible with human dignity.

13. Distortions in revealing the true political preferences, as a result of supporting an unwanted party during the elections.

14. Bad image of private transportation system that caused the city of Istanbul a loser during the candidacy for the 2004 Olympic games.

15. Lower quality of living standards prevails in the squatter type of new settlement areas.

16. Increase in the number of psychosomatic diseases as a result of environmental pollution and congestion.

17. Fear of being injured or killed at a traffic accident. 


\section{d) Some Empirical Studies}

Since cost benefit analysis is not employed in public projects in Turkey there are only few empirical studies made in the field of effectiveness of rail transportation. Some findings are as follows.

- It is estimated that 2.8 million ton petroleum could be saved, provided that the share of the rail transportation is doubled. ${ }^{6}$

- Number of the people living in slums area constitutes at least $60 \%$ of the total population of Istanbul. Former bridges over the Bosphorus is blamed for the increase of bad housing conditions. ${ }^{7}$

- Road transportation is found at least 3000 times riskier than the rail. 8

- The cost of construction of per $\mathrm{km}$ of express highways is about the same that of high speed railways. It is estimated that cost of construction of per $\mathrm{km}$ is about 7 hundred thousand dollars. ${ }^{9}$

\section{e) Importance of Pressure Groups in the Choice of Projects}

The respective cost benefit analysis developed above foresees the Channel Tunnel Project to be preferred to 3rd Bridge project from the economic point of view. Nevertheless, well organized pressure groups exert heavy influence on the decision making bodies. For this reason, they determine the project to be chosen, which will maximize their profits.

The following cases briefly explain how the pressure groups play important role in choosing the least feasible projects as opposing to the projects with highest social benefits.

1. Bursa-Uludağ Teleferic Line: A teleferic line connecting the city of Bursa to the famous ski resort at the top of the Uludag (historical mount Olympus) was planned about 50 years ago. According to original project, this teleferic line had three station. But, Association of Bursa Taxi Drivers exerted considerable pressure on the local authorities and successfully reduced the number of staions from three to two. Accordingly, passengers taking teleferic have to take taxi or minibus after getting off the last station, in order to reach to ski resort and to the hotels. But, this type of combined transportation system is not efficient, because, one has to wait for a taxi or minibus for hours, especially durring the winter session. 
For this reason, passengers have to take taxi or minibus in the city if they want to reach to the ski resort area. But the social costs of this alternative trip is too high. Because it causes at least one hour delay, traffic accidents and extra travelling costs. On the other hand, one loses the opportunity of enjoying a breathtaking scenery of the mountain, if the trip were otherwise taken by the teleferic.

Although, local administrations had tried to extend the teleferic line to the hotels, in order to encourage the tourism but they failed, owing to heavy pressure exerted by the well organized pressure groups. Local authorities are not likely to break the resistance of Association of Bursa Taxi Drivers. Even though, the realization of the project will save time, reduce petroleum consumption and the traffic accidents.

2. Cancellation of Yalova-Thermal Municipality Bus Line: $A 12 \mathrm{~km}$ long municipality bus line, connecting city of Yalova to Thermal district and famous hot spring resort, was cancelled last year. The reason for the cancellation was closely related to the strong competition between the private transportation and the municipality operated buses."

Although, municipality buses were not subsidized by the administration, but they have been operated much more efficiently than the minibuses run by the private companies They were also comfortable and more secure than the minibuses. Besides that, they charged lesser prices than the private transportation modes.

In order to charge their higher pricing policies, Assocation of Yalova Minibus Drivers exerted strong influence on the local authorities and had the municipality to cancel the Bus Line. The result is increased prices, insecurity and uncomfortable trip. In addition to these, environmental, noise and air pollution is increased.

3. Sincan-Arifiye High Speed Train Project: This project reduces the travelling time from 7-12 hours to 2.5 hours, by shortening the existing railroad between Ankara and Istanbul, from $575 \mathrm{~km}$ to $417 \mathrm{~km}$. It is designed to have double track rail which eliminates the long delays and congestion problems. The length of the high speed railroad is $260 \mathrm{~km}$ and it will be electrified. This high speed train project will replace the the existing old railway, which is not comfortable, secure and fast. The existing railway also can't compete with intercity road transportation and buses, one can take the $450 \mathrm{~km}$ long highway (between Ankara and Istanbul) within 5-7 hours.

" However, after one year long break, the line was opened in 1998. 
For this reason, pessengers prefer to take buses, even though it is very risky as to traffic accidents. On the other hand, road transportation generates important negative externalities in the form of increasing petroleum consumption and environmental pollution stated before. Hower, some people still prefer to take trains since it is comfortable, secure and romantic even though it is not fast enough.

Although, High Speed Rail Project has been planned in 1976 and public tender "has been made, but it is unfortunate that the project is not completed yet. It is argued that, reason for the delay is closely related to the adverse political considerations. In fact, Directorate of Highways was purposedly separated from the Ministry of Transportation in 1950's.

Firstly, rail transportation is regarded as a mode which is peculiar to communist system. This has been openly stated by a former prime minister and the president in 1980's. Secondly, Association of Intercity and International Drivers are very strong pressure groups. In fact, they are strong enough to play a role in the appointment of top level of public bureaucrats at the ministry of transportation. Thirdly, voters are not supporting the political parties that give national priorities to railways.

4. Decreasing Importance of Sea Transportation in Istanbul: Istanbul is located on two peninsula, the one is on the Europe and the other is on Asian continent. Owing to its geographical location, sea transportation system would be the most efficient among the other modes of transportation. But this cheapest transportation system is not used efficiently, on account of the resistance of the same pressure groups mentioned above. In spite of the increasing number of the passengers, many ferry landing ports and the wharfs have been closed so far. Instead new bus and minibus lines are opened, owing to deregulation of public transportation.

Of course, the social opportunity cost of this minibus and bus dominated land transportation is very high. Firstly, it is expensive and time consuming. In addition to this, all types of pollution and congestion problems are generated. Secondly, many passengers are deprived of enjoying the one of the most beautiful scenery in the world, that the Bosphorus provides. In addition to these, many scheduled boat trips along with Bosphorus had been cancelled. However, 2 or 3 daily boat trips are organised on behalf of tourists, which is very expensive for the working people. For these reason, people living in suburbans have to take traditional land transportation means. 


\section{f) Evaluation of Theoretical Aspects of Cost Benefit Analysis}

The modern interpreation of cost and benefit analysis as it is stated in public economic text books, doesn't count the pecuniary benefits in real sense. As a matter of fact that, pecuniary costs and benefits are not regarded as net loss or gain to the community. And, for this reason they are not included in cost and benefit of a project. But, this reasoning of pecuniary costs and benefits fails to explain their importance, as to developing countries are concerned.

Unlike in developed countries, where the social balance (as understood by J. Kenneth Galbarith) is secured to some ceratin degree doesn't prevail in developing countries. This means that, serious misallocation problems are not present in developed countries. For this reason, pecuniary costs and benefits may not be that important, as in developing countries. But as far as developing countries are concerned, there is a serious misallocational problems stemming from the fact that, social imbalance prevails. Thus overallocation of the factor of productions to producing private goods is likely to increase the pecuniary costs and benefits. This holds true for the project that I present to this conference.

For instance, pecuniary benefits in terms of speculative income earned from the land and housing increased astronomically, as a result of two former realized bridge projects.

But, the high rise in the bridge related income, heavily distorted the state of income distribution, which was unfair before the projects were undertaken. In fact, bridges not only increased the value of the lands around, but the suburban area where the connecting roads are leading were also appreciated. For this reason, high and middle income groups invested their savings on lands rather than on productive investments. Thus, speculation on bridge related lands created a new high income group. For this reason, pecuniary benefits generated by the bridge projects caused serious unfair income distribution and misallocation of the scare sources and the very limited savings.

Since, the special assessment tax on the appreciated value of land abolished in 1980 's, earnings from the untaxed speculative income became very attractive. For this reason, not only the pressure groups but also the land speculators are strongly against to Channel Tunnel Project. It is unfortunate that both groups exert considerable influence on decision makers at local and central levels. 
On the other hand, unfair income distribution as a consequence of bridge related project, adversely affects the proper appropriation of the scare sources in their competitive usage. Thus, misappropriation of the scare resources causes serious stabilization problems.

This is why I like to emphasize the importance of the pecuniary costs and benefits in cost benefit analysis. In fact, pecuniary costs of the public projects not only result in distortions from the fair income distribution, proper allocation and stabilization goals of the fiscal policy, but it also causes serious social problems. We call them "gecekondu mafyası" or slum mafia, those organized criminal groups whose members market speculative lands, owing to bridge related projects. In addition to that civil servants become bribe takers, in exchange for the information given to speculators about the destination of the new connecting roads of the bridges and settlement areas. Thus, pecuniary benefits as a result of insider trading increases the corruption in public sector.

\section{Pigovian Type Externalities}

In the theory of public economics, studies added sophistication to the Pigovian analysis concerning the conceptual aspects of externalities. It seems to me potential positive externalities that would be generated by the Channel Tunnel Project, should be viewed in terms of Pigovian externalities. This is because of the fact that, sources are predominantly allocated to private transportation, both in Turkey and in the city of Istanbul.

Therefore, greater gain in walfare will occur from internalizing or correcting potential externalities through reallocation to metro project. In this case, the marginal cost of providing following public untilities would be zero, if these subprojects were integrated to the metro project. These subprojects are:

- sewage and canalization.

- cable TV and PTT cables,

- natural gas,

- electricity and

- provision of shelter for the citizens during the chemical wars.

It is unfortunate that these public utilities are not projected and installed into metro 
tunnels in Istanbul. Thus, alternative opportunity benefits of these subprojects are forgone. If they were included in the main project, the administration would have saved a great deal of money, since marginal cost of zero case applicable. Actually, the subprojects mentioned above, involve different invesment projects if they are undertaken separetely, Their inclusion to metro project would not only yield positive externalities or indirect tangible and intangible benefits (as described at page 9-15) but also considerable opportunity benefit as stated here.

- provision of their installation cost at zero,

- no extra digging of the pavements is necessary,

- people are not disturbed, from the diggings,

- repairment and maintenance costs are minimized.

Opportunity benefits of the rail project as classified above will also reduce the cost of metro, if sources are reallocated from the ovelallocated private transportation to public.

\section{Conclusion}

As I explained above, the Channel Tunnel Project is likey to generate Pigovian type of externalities calling for international cooperation among the concerned countries. Because, if this project is undertaken only by Turkey, potential postitive externalities and the spilover benefits wouldn't accrue to the involved countries. Nevertheless, as I tried to explain in this paper, this project will not to be given first priority, due to strong resistance of powerful pressure groups, and lack of financial supports, even though it is indispensable. Besides that, undertaking three rail related projects by the different administrations will eventually reduce the efficiency of these projects; namely, metro, tunnel channel and suburban trains. In this case, economics of scale and decreasing marginal cost principles are violated resulting in duplication of services and thus incerasing the cost of projects. For these reasons Channel Tunnel Project should be regarded as an international public goods that will help to allocate the resources efficiently and distribute the income fairly among the concerned nations. If otherwise, reciprocal possible externalization of these positive externalities requires developed countries to involve in high speed train project connecting Western cities to the Asian countries and extension of this project to the Eastern coast of China or Korea through the Channel Tunnel under the Bosphorus Strait in Istanbul. 
According to modern public economics, pecuniary costs and the benefits are not regarded net loss and gain to community as a whole, and they are not included when considering efficiency aspects of cost benifit analysis. But, in developing countries pecuniary effects may some time be much more important than the indirect benefits.

For instance, prices of the lands nearby the bridges increased dramatically as a result of former bridge projects, in Istanbul. Since, there is no special assessment tax in Turkey, these speculative income gained from the lands nearby the bridges violated fairness in income distribution.

On the other hand, untaxed high level of speculatie income also heavily distorted the income distribution, which was not fair before the bridge projects had been realized. For this reason, contary of public economics, they should be included in the calculations of cost-benefits of the projects, undertaken in developing countries.

\section{Endnotes}

${ }^{1}$ State Planning Organisation, Seventh Five Year Plan (1996-2000), Ankara, 1996, pp. 124-125.

2 Ekinci, O., "Transformation File", Cumhuriyet, August 21, 1995.

${ }^{3}$ Şener, O., Integration of Turkish Transportation System to European Community, TUSIAD, 1989, Istanbul.

4 Musarave, R. - Musarave P., Public Finance in Theory and Pratice, McGraw Hill, London.

5 Şener, O., Public Economics (5th ed) Beta Publishing Company, Istanbul, 1996, P. 122-123.

${ }^{6}$ Arıoğlu, E., Energy Saving Policies, TMMO, Istanbul, May 1995 P. 27.

7 Ibid, P. 217.

8 Arıoğlu, E. Tezcan, S., "Metro, as the Most Reliable Transportation Means in Energy Saving Policy“, Dünya. 18.05.89.

${ }^{9}$ Cumhuriyet, March 19. 1996 